\title{
WPLYW ZMIAN STANDARDÓW OPCJI NA RYNEK OPCJI INDEKSOWYCH NA GIEŁDZIE PAPIERÓW WARTOŚCIOWYCH W WARSZAWIE
}

\author{
Katarzyna Królik-Kołtunik \\ Zakład Rynków Finansowych \\ Uniwersytet Marii Curie-Skłodowskiej
}

\begin{abstract}
Abstrakt. Opcje są pochodnymi instrumentami finansowymi pozwalającymi na konstruowanie wielu strategii inwestycyjnych. Warunkiem ich budowania jest odpowiednia różnorodność instrumentów i ich płynność. Władze warszawskiej giełdy modyfikują standardy opcji odpowiadając na potrzeby inwestorów. Celem niniejszej pracy jest określenie, czy działania w tym zakresie spowodowały wzrost zainteresowania opcjami indeksowymi na Giełdzie Papierów Wartościowych w Warszawie. W badaniach poddano analizie różne parametry rynku opcji m.in. liczbę serii, wolumen i wartość obrotu, a także liczbę otwartych pozycji.
\end{abstract}

Słowa kluczowe: opcje indeksowe, instrumenty pochodne, giełda, rynek kapitałowy

\section{WSTĘP}

Opcje są instrumentem finansowym dającym wiele zróżnicowanych możliwości inwestowania. Należą one do grupy instrumentów pochodnych, a więc ich cena jest uzależniona od innego instrumentu finansowego, określanego jako instrument bazowy. Konstrukcja opcji umożliwia inwestorom stosowanie wielu różnorodnych strategii, zarówno spekulacyjnych, jak i zabezpieczających, a także arbitrażowych. Jednak warunkiem niezbędnym do tworzenia wszelkich strategii, czy to prostych, czy złożonych, jest odpowiednia płynność na rynku.

Pojęcie płynności można odnieść zarówno do pojedynczych aktywów, jak i do całego rynku [Francis 2000]. Aktywa uważane za doskonale płynne można szybko spieniężyć bez żadnych problemów po aktualnej cenie. Niedostateczna płynność 
lub jej brak powodują pojawienie się ryzyka płynności (może ono dotyczyć instrumentów finansowych lub innych aktywów, np. nieruchomości), polegającego na zaniżaniu cen w sytuacji kłopotów ze zbyciem lub zawyżaniu cen w przypadku problemów z nabyciem określonych aktywów [Ostrowska 2011]. Problemy z płynnością powodują pojawienie się dodatkowych kosztów realizacji, określanych także mianem transakcyjnych, wśród których wymienia się efekt wielkości transakcji, niedokładne rozpoznanie ceny, prowizje maklerskie oraz widełki cen kupna-sprzedaży [Hasbrouck i Schwartz 1988].

Płynność opcji, których dotyczy niniejsze opracowanie, jest ściśle związana $\mathrm{z}$ ich wyceną. Badania w tym zakresie przeprowadzili m.in. Chou, Chung, Hsiao, Wang [2011]. Niewłaściwa wycena opcji umożliwia przeprowadzenie zyskownych transakcji arbitrażowych, które są niekiedy wykorzystywane m.in. do określania efektywności rynku. Dotychczasowe badania wskazują, że na Giełdzie Papierów Wartościowych w Warszawie możliwe było osiąganie zysków arbitrażowych na rynku opcji indeksowych [Królik-Kołtunik 2010a, b, 2012]. Jednakże niewłaściwa wycena nie zawsze musi świadczyć o nieefektywności rynku z uwagi na ograniczenia w przeprowadzeniu arbitrażu [Ackert i Tian 2000].

Na Giełdzie Papierów Wartościowych w Warszawie od 2003 roku są notowane opcje indeksowe, dla których instrumentem bazowym jest główny indeks warszawskiej giełdy - WIG20. W latach 2005-2007 notowane były opcje na akcje wybranych największych spółek, jednak z powodu niewielkiego zainteresowania inwestorów obrót nimi został zawieszony, i jak na razie nie przywrócono handlu tym instrumentem. Zarząd giełdy podejmuje działania mające na celu zapewnienie płynności obrotu opcjami indeksowymi. Jednym z nich jest podpisanie umowy z podmiotem, którym będzie świadczył usługi animatora rynku dla danego instrumentu. Obecnie (październik 2016) cztery podmioty ${ }^{1}$ są animatorami dla opcji indeksowych notowanych na Giełdzie Papierów Wartościowych w Warszawie. Innym rodzajem działań podejmowanych przez giełdę jest dostosowanie standardów opcji do potrzeb i oczekiwań inwestorów oraz rynku. Celem tego artykułu jest określenie, czy zmiany wprowadzane przez zarząd giełdy $\mathrm{w}$ standardach opcji wpłynęły na rynek opcji na indeks WIG20, w szczególności na jego płynność. Jak dotąd nie pojawiły się opracowania sprawdzające skuteczności działań warszawskiej giełdy $w$ tym zakresie.

\section{METODY BADAŃ}

W pierwszej części pracy zaprezentowane zostały zmiany dokonywane w standardach opcji indeksowych notowanych na Giełdzie Papierów Wartościowych $\mathrm{w}$ Warszawie. Wprowadzane zmiany miały poprawić funkcjonowanie rynku opcji i zwiększyć zainteresowanie inwestorów tym instrumentem. W dalszej części pra-

\footnotetext{
${ }^{1}$ Są to członkowie giełdy: Raiffeisen bank SA, PKO BP SA, DM BOŚ SA oraz mBank SA.
} 
cy w celu weryfikacji działań władz giełdy sprawdzono, jak kształtowały się podstawowe parametry rynku opcji, takie jak liczba serii opcji w obrocie, wolumen i wartość obrotów opcjami, liczba otwartych pozycji i ich wartość, a także średnia liczba transakcji na sesję i średnia liczba kontraktów na transakcję. Ponadto zbadano także procentowe zmiany tych wielkości w ujęciu miesiąc do miesiąca. Analizowano dane całościowe dla obu typów opcji - kupna i sprzedaży. Dodatkowo porównano średnie wielkości badanych parametrów z okresu 24 miesięcy przed wprowadzeniem i po wprowadzeniu zmian standardów oraz sprawdzono statystyczną istotność różnic pomiędzy nimi.

Jednym z parametrów wykorzystywanym do zmierzenia płynności rynku opcji są widełki cenowe kupna-sprzedaży (zob. badania Mo [2015]). Niestety GPW nie udostępnia danych dotyczących spreadu, nie można było więc wykorzystać tego miernika.

Badaniem objęto lata 2003-2016. Ustalenie takiego okresu pozwoliło obserwować rynek opcji od początku jego istnienia (wrzesień 2003) i uwzględnić najnowsze dostępne dane (wrzesień 2016). Analizowano dane u ujęciu miesięcznym, więc ciąg obserwowanych danych liczył 157 okresów dla każdej z sześciu analizowanych wielkości. Wyjątkiem była liczba serii na koniec roku. W pracy wykorzystano dane udostępnione przez Giełdę Papierów Wartościowych w Warszawie w Rocznikach Giełdowych.

\section{ZMIANY STANDARDÓW OPCJI}

Instrumenty pochodne notowane na rynku regulowanym cechują się standaryzacją, tzn. pewne parametry są ściśle określone (niejako narzucone przez organizatora obrotu) i nie podlegają negocjacji przez kupujących i sprzedających. Nie inaczej jest w przypadku warszawskiej giełdy. Zarówno opcje, jak i kontrakty terminowe notowane na GPW mają swoje standardy. Standard opcji jest więc pewnego rodzaju charakterystyką opcji, w którym można znaleźć opis wszystkich istotnych cech tego instrumentu. Przykładowymi elementami określanymi w standardzie opcji są: nazwa, instrument bazowy, styl wykonania, sposób rozliczenia, termin wygaśnięcia, kursy wykonania, zasady ustalania kursu rozliczeniowego, jednostka notowania, sposób ustalania wartości opcji, a także wiele innych.

Pierwsze przepisy wprowadzające standaryzację opcji pojawiły się w 2003 roku. Zostały zawarte w uchwale Rady Giełdy z dnia 19 lutego 2003 roku. ${ }^{2}$ Przepisy znalazły zastosowanie 22 września 2003 roku, gdy rozpoczął się handel opcjami indeksowymi na GPW w Warszawie. Standard opcji był wielokrotnie zmieniany, co miało na celu lepsze dopasowanie instrumentu do oczekiwań i potrzeb inwestorów. Zestawienie najważniejszych zmian zostało zamieszczone w tabeli 1.

${ }^{2}$ Uchwała Nr 11/977/2003 Rady Giełdy Papierów Wartościowych w Warszawie S.A. z dnia 19 lutego $2003 \mathrm{r}$. 
TABELA 1. Najważniejsze zmiany standardów opcji indeksowych w latach 2003-2016

\begin{tabular}{|c|c|c|c|}
\hline $\begin{array}{c}\text { Data } \\
\text { uchwalenia } \\
\text { zmian } \\
\end{array}$ & $\begin{array}{c}\text { Data } \\
\text { wprowadzenia } \\
\text { zmian } \\
\end{array}$ & Stan przed zmianą & Stan po zmianie \\
\hline 1 & 2 & 3 & 4 \\
\hline 21.02.2007 & 19.03.2007 & $\begin{array}{l}\text { Po wygaśnięciu poprzednich se- } \\
\text { rii do obrotu giełdowego wpro- } \\
\text { wadza się po cztery serie opcji } \\
\text { kupna i sprzedaży: } 1 \text { opcję ATM, } \\
1 \text { opcję ITM i } 2 \text { opcje OTM. }\end{array}$ & $\begin{array}{l}\text { Po wygaśnięciu poprzednich } \\
\text { serii do obrotu giełdowego } \\
\text { wprowadza się po dziewięć } \\
\text { serii opcji kupna i sprzedaży: } \\
1 \text { opcję ATM, } 4 \text { opcje ITM i } 4 \\
\text { opcje OTM. }\end{array}$ \\
\hline 02.10 .2007 & 15.10 .2007 & $\begin{array}{l}\text { Terminy wygaśnięcia opcji } \\
\text { to dwa najbliższe miesiące } \\
\text { z tzw. marcowego cyklu kwar- } \\
\text { talnego. }\end{array}$ & $\begin{array}{l}\text { Terminy wygaśnięcia opcji } \\
\text { to cztery najbliższe miesiące } \\
\text { z tzw. marcowego cyklu kwar- } \\
\text { talnego. }\end{array}$ \\
\hline 06.02 .2009 & 20.02 .2009 & $\begin{array}{l}\text { Kurs rozliczeniowy oblicza- } \\
\text { ny jako średnia arytmetyczna } \\
\text { z wszystkich wartości indeksu } \\
\text { WIG20 z ostatniej godziny no- } \\
\text { towań oraz wartości indeksu } \\
\text { ustalonej podczas zamknięcia } \\
\text { sesji. }\end{array}$ & $\begin{array}{l}\text { Kurs rozliczeniowy oblicza- } \\
\text { ny jako średnia arytmetyczna } \\
\text { z wszystkich wartości indeksu } \\
\text { WIG20 z ostatniej godziny no- } \\
\text { towań oraz wartości indeksu } \\
\text { ustalonej podczas zamknięcia } \\
\text { sesji, po odrzuceniu skrajnych } \\
\text { wartości: } 5 \text { najniższych i } 5 \text { naj- } \\
\text { wyższych. }\end{array}$ \\
\hline 02.03.2012 & 19.03.2012 & $\begin{array}{l}\text { Dla wszystkich terminów wy- } \\
\text { gaśnięcia różnice pomiędzy } \\
\text { kursami wykonania poszcze- } \\
\text { gólnych serii opcji to } 100 \text { pkt } \\
\text { dla kursów przekraczających } \\
1000 \text { pkt* }\end{array}$ & $\begin{array}{l}\text { Dla opcji o najbliższym ter- } \\
\text { minie wygaśnięcia różnice } \\
\text { pomiędzy kursami wykonania } \\
\text { poszczególnych serii opcji to } \\
50 \text { pkt dla kursów przekra- } \\
\text { czających } 1000 \text { pkt. Dla pozo- } \\
\text { stałych terminów wygaśnięcia } \\
\text { różnice pomiędzy kursami wy- } \\
\text { konania poszczególnych serii } \\
\text { opcji to } 100 \text { pkt dla kursów } \\
\text { przekraczających } 1000 \text { pkt. }\end{array}$ \\
\hline 27.02.2014 & 17.03 .2014 & $\begin{array}{l}\text { Skrócona nazwa opcji tworzo- } \\
\text { na wg zasad: OXYZkrccc. }\end{array}$ & $\begin{array}{l}\text { Skrócona nazwa opcji tworzo- } \\
\text { na wg zasad: OXYZkrrcccc. }\end{array}$ \\
\hline 14.07.2014 & 18.08.2014 & $\begin{array}{l}\text { Terminy wygaśnięcia opcji } \\
\text { to cztery najbliższe miesiące } \\
\text { z tzw. marcowego cyklu kwar- } \\
\text { talnego. }\end{array}$ & $\begin{array}{l}\text { Terminy wygaśnięcia opcji to } \\
\text { trzy najbliższe miesiące kalen- } \\
\text { darzowe oraz trzy kolejne mie- } \\
\text { siące z tzw. marcowego cyklu } \\
\text { kwartalnego. }\end{array}$ \\
\hline
\end{tabular}


cd. tabeli 1

\begin{tabular}{|c|c|c|c|}
\hline 1 & 2 & 3 & 4 \\
\hline 14.07 .2014 & 18.08 .2014 & $\begin{array}{l}\text { Dla opcji o najbliższym termi- } \\
\text { nie wygaśnięcia różnice po- } \\
\text { między kursami wykonania } \\
\text { poszczególnych serii opcji to } \\
50 \text { pkt dla kursów przekra- } \\
\text { czających } 1000 \text { pkt. Dla pozo- } \\
\text { stałych terminów wygaśnięcia } \\
\text { różnice pomiędzy kursami } \\
\text { wykonania poszczególnych se- } \\
\text { rii opcji to } 100 \text { pkt dla kursów } \\
\text { przekraczających } 1000 \text { pkt. }\end{array}$ & $\begin{array}{l}\text { Dla opcji o najbliższym terminie } \\
\text { wygaśnięcia różnice pomiędzy } \\
\text { kursami wykonania poszcze- } \\
\text { gólnych serii opcji to } 25 \text { pkt } \\
\text { dla kursów przekraczających } \\
1000 \text { pkt. } \\
\text { Dla opcji o kolejnych dwóch } \\
\text { terminach wygaśnięcia różnice } \\
\text { pomiędzy kursami wykonania } \\
\text { poszczególnych serii opcji to } \\
50 \text { pkt dla kursów przekraczają- } \\
\text { cych } 1000 \text { pkt. Dla pozostałych } \\
\text { terminów wygaśnięcia różnice } \\
\text { pomiędzy kursami wykonania } \\
\text { poszczególnych serii opcji to } \\
100 \text { pkt dla kursów przekra- } \\
\text { czajacych } 1000 \text { pkt. }\end{array}$ \\
\hline
\end{tabular}

* W standardzie opcji są również podane różnice pomiędzy kursami dla kursów wykonania poniżej 1000 pkt.

Źródło: Opracowanie własne.

Pierwsze znaczące zmiany miały miejsce w 2007 roku. Zwiększono wówczas liczbę serii wprowadzanych do obrotu. Zarząd giełdy w uchwale z dnia 21 lutego 2007 roku $^{3}$ podjął decyzję o zwiększeniu liczby serii opcji znajdujących się w obrocie. Dotychczas po wygaśnięciu poprzednich serii opcji od obrotu giełdowego były wprowadzane opcje z nowym terminem wygaśnięcia i z takimi kursami wykonania, aby w obrocie przynajmniej jedna opcja była at-the-money (ATM), jedna opcja była in-the-money (ITM) i dwie opcje były out-of-the-money (OTM). W przypadku, gdy kurs instrumentu bazowego wzrósł lub spadł, to do obrotu były wprowadzane kolejne opcje tak, aby dla inwestorów zawsze były dostępne po jednej opcji ATM i ITM oraz dwie opcje OTM. Zasady te odnosiły się zarówno do opcji kupna, jak i sprzedaży. Po wprowadzeniu zmian, w handlu zawsze znajdują się przynajmniej jedna seria opcji ATM i po cztery serie opcji ITM i OTM. W sumie dla każdego terminu wygaśnięcia co najmniej 18 serii opcji kupna i sprzedaży.

Kolejne zmiany również miały miejsce w 2007 roku. Zarząd giełdy w uchwale z dnia 2 października 2007 roku ${ }^{4}$ podjął decyzję o zwiększeniu ilości terminów wygaśnięcia opcji z dwóch do czterech. Po wejściu w życie wspomnianych przepi-

\footnotetext{
${ }^{3}$ Uchwała Nr 135/2007 Zarządu Giełdy Papierów Wartościowych w Warszawie S.A. z dnia 21 lutego $2007 \mathrm{r}$.

${ }^{4}$ Uchwała Nr 772/2007 Zarządu Giełdy Papierów Wartościowych w Warszawie S.A. z dnia 2 października $2007 \mathrm{r}$.
} 
sów opcje wygasają w czterech najbliższych miesiącach z tzw. marcowego cyklu kwartalnego (marzec, czerwiec, wrzesień, grudzień). Wskutek tych zmian, „okres życia" opcji wprowadzanych do obrotu zgodnie z cyklem będzie trwał 12 miesięcy, a nie 6 miesięcy, jak przed wprowadzeniem zmian.

Ważne zmiany w standardzie opcji miały miejsce w 2009 roku. Uchwałą z dnia 6 lutego $2009 \mathrm{roku}^{5}$. Zarząd giełdy zmodyfikował sposób ustalania kursu rozliczeniowego. Do dotychczas obowiązującej zasady, w myśl której kurs rozliczeniowy był obliczany jako średnia arytmetyczna z wszystkich wartości indeksu WIG20 z ostatniej godziny notowań oraz wartości indeksu ustalonej podczas zamknięcia sesji, dodano zastrzeżenie, iż skrajne wartości nie będą brane pod uwagę. Odrzuca się po pięć najwyższych i najniższych wartości. Zmiany te miały na celu ograniczenie, a nawet uniemożliwienie ewentualnych prób manipulacji kursem.

Następne zmiany zostały przeprowadzone w 2012 roku. Zarząd giełdy w uchwale z dnia 2 marca 2012 roku $^{6}$ podjął decyzję o „zagęszczeniu” kursów wykonania opcji o najbliższym terminie wygaśnięcia. Do tego momentu różnice pomiędzy kursami wykonania opcji wynosiły 100 punktów, jeśli kurs wykonania przekraczał 1000 punktów, bez względu na termin wygaśnięcia opcji. Po wprowadzeniu zmian kursy wykonania opcji o najbliższym terminie wygaśnięcia miały różnić się o 50 punktów. Na skutek tych zmian uległa zwiększeniu liczba serii w obrocie. Opcji o najbliższym terminie wygaśnięcia powinno być przynajmniej 17 serii dla każdego typu opcji (kupna i sprzedaży): 1 ATM, 8 ITM i 8 OTM, a opcji o dalszych terminach wygaśnięcia - przynajmniej 9 serii dla każdego typu opcji: 1 ATM, 4 ITM i 4 OTM (tak jak dotychczas).

W 2014 roku miały miejsce dwie znaczące modyfikacje standardów opcji, z czego pierwsza była pewnego rodzaju przygotowaniem do drugiej. W uchwale $\mathrm{z}$ dnia 27 lutego $2014 \mathrm{roku}^{7}$. Zarząd giełdy dokonał zmian w stosowanych nazwach opcji. Dotychczas skrócone nazwy opcji były konstruowane w następujący sposób:

OXYZkrccc

gdzie:

0 - rodzaj instrumentu (czyli opcja),

XYZ - kod określający nazwę instrumentu bazowego, określony w uchwale zarządu giełdy (dla opcji na indeks WIG20, zastosowany kod to W20),

k - kod określający typ i miesiąc wygaśnięcia opcji, określony w uchwale zarządu giełdy,

\footnotetext{
${ }^{5}$ Uchwała Nr 71/2009 Zarządu Giełdy Papierów Wartościowych w Warszawie S.A. z dnia 6 lutego $2009 \mathrm{r}$.

${ }^{6}$ Uchwała Nr 188/2012 Zarządu Giełdy Papierów Wartościowych w Warszawie S.A. z dnia 2 marca $2012 \mathrm{r}$.

${ }^{7}$ Uchwała Nr 229/2014 Zarządu Giełdy Papierów Wartościowych w Warszawie S.A. z dnia 27 lutego $2014 \mathrm{r}$.
} 
r - ostatnia cyfra roku wygaśnięcia,

ccc - oznaczenie kursu wykonania ${ }^{8}$.

Po wprowadzeniu modyfikacji skrócone nazwy opcji są tworzone w podany sposób:

OXYZkrrcccc

gdzie:

0 - rodzaj instrumentu,

XYZ - kod określający nazwę instrumentu bazowego,

$\mathrm{k}$ - kod określający typ i miesiąc wygaśnięcia opcji,

rr - dwie ostatnie cyfry roku wygaśnięcia,

cccc - kurs wykonania.

Obecnie podawane są dwie ostatnie cyfry roku wykonania opcji zamiast jednej ostatniej, a także w nazwie opcji widoczny jest pełny (czterocyfrowy) kurs wykonania opcji. Zmiany te były przygotowaniem do kolejnego „zagęszczenia” kursów wykonania, które nastąpiło w sierpniu tego samego roku decyzją zarządu giełdy w uchwale z dnia 14 lipca 2014 roku$^{9}$. W tej samej uchwale zmieniony został również cykl wygasania opcji, wprowadzono nowe terminy ich wygaśnięcia. Pojawiły się tzw. opcje miesięczne, chociaż jest to do pewnego stopnia „skrót myślowy". W momencie wprowadzania nowych serii opcji do obrotu giełdowego po wygaśnięciu poprzednich, mają one terminy 3- lub 12-miesięczne, w zależności od miesiąca wygaśnięcia opcji ${ }^{10}$. Jednak jeśli spojrzy się na opcje o najbliższym terminie wygaśnięcia, to będą one wygasały maksymalnie za miesiąc, stąd stosowane określenie „opcje miesięczne”.

Zmniejszono także różnice pomiędzy kursami wykonania dla opcji o najbliższym (miesięcznym) terminie wygaśnięcia, obecnie wynoszą one 25 punktów dla kursów wykonania przekraczających 1000 punktów. Dla opcji o kolejnych dwóch terminach wygaśnięcia kursy wykonania różnią się o 50 punktów dla kursów wykonania przekraczających 1000 punktów. Dla pozostałych terminów wygaśnięcia różnice wynoszą, tak jak poprzednio, 100 punktów.

Ostatnie zmiany z 2014 roku doprowadziły do znaczącego zwiększenia się ilości serii w obrocie. Dla opcji o najbliższym terminie wygaśnięcia w obrocie znaj-

\footnotetext{
${ }^{8}$ Było to tylko oznaczenie, a nie pełny kurs wykonania, np. kurs wykonania 2500 miał oznaczenie 250, a kurs wykonania 2350 miał oznaczenie 235 . W sytuacji, gdy kolejne kursy wykonania były ustalane co 100, a później także co 50 punktów (więc zawsze kończyły się zerem), ostatnia cyfra była pomijana.

${ }^{9}$ Uchwała Nr 804/2014 Zarządu Giełdy Papierów Wartościowych w Warszawie S.A. z dnia 14 lipca $2014 \mathrm{r}$.

${ }^{10} \mathrm{~W}$ przypadku opcji wygasających w marcu, czerwcu, wrześniu i grudniu, wprowadzane są opcje o 12-miesięcznym terminie wygaśnięcia, a w przypadku opcji wygasających w pozostałych miesiącach, czyli w styczniu, lutym, kwietniu, maju, lipcu, sierpniu, październiku i listopadzie, wprowadzane są opcje o 3-miesięcznym terminie wygaśnięcia.
} 
duje się 1 seria opcji ATM, co najmniej 16 serii ITM, 16 serii OTM, dla opcji o dwóch kolejnych terminach wygaśnięcia 1 seria ATM, co najmniej 8 serii ITM i 8 serii OTM, zaś dla trzech kolejnych terminów 1 seria ATM, 4 serie ITM i 4 serie OTM.

\section{WYNIKI BADAŃ}

Większość spośród wprowadzanych zmian miała na celu zwiększenie ilości serii w obrocie, np. wprowadzenie dodatkowych terminów wygaśnięcia opcji czy zmniejszanie różnic pomiędzy kursami wykonania opcji z najbliższymi terminami wygaśnięcia. Początkowo minimalna liczba serii w obrocie wynosiła 16 (po 4 serie opcji kupna i sprzedaży dla każdego z dwóch terminów wygaśnięcia). Kolejne zmiany zwiększały minimalną liczbę serii w obrocie kolejno do 36,72 , 88, a wskutek ostatnich modyfikacji z 2014 roku do 188.

Na rysunku 1 zaprezentowane zostały dane dotyczące liczby serii opcji indeksowych znajdujących się w obrocie na koniec kolejnych lat. Z wyjątkiem 2003 roku liczba serii jest większa od minimalnej, co ma związek ze zmianami wartości instrumentu bazowego, które skutkują wprowadzaniem kolejnych serii tak, aby zawsze inwestorzy mieli dostęp od określonej liczby opcji in-the-money i out-of-the-money. Dane dotyczące 2008 roku obrazują tę zasadę. W latach 2007-2008 wartość indeksu WIG20 zmieniała się znacząco w krótkim czasie, więc konieczne było wprowadzanie nowych serii opcji z dodatkowymi kursami wykonania, podążającymi za tymi zmianami. Największy wzrost liczby serii opcji w obrocie miał miejsce w 2014 roku, kiedy to jednocześnie wprowadzono opcje z nowymi terminami wygaśnięcia i z dodatkowymi kursami wykonania. Minimalna liczba serii wzrosła skokowo z 88 do 188 . To potwierdza, że działania giełdy w tym zakresie przyniosły oczekiwane efekty. Następował wzrost liczby serii opcji w obrocie.

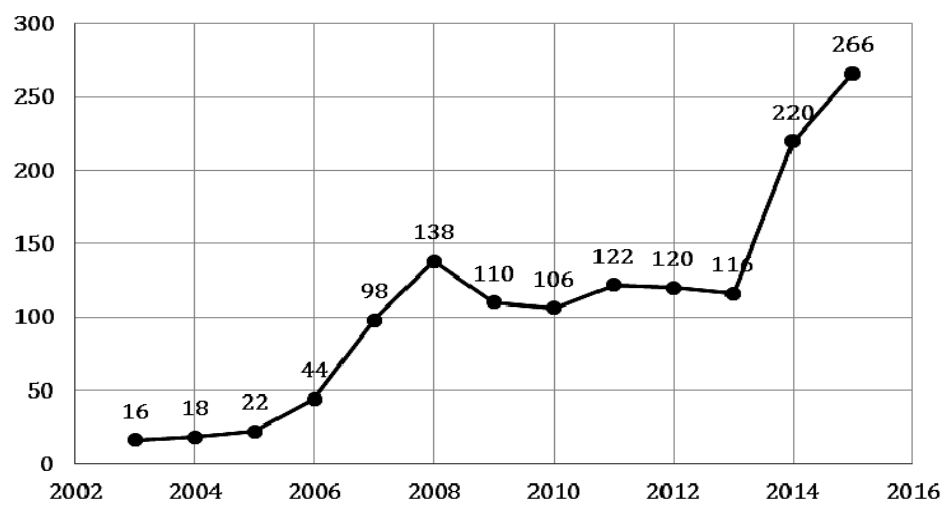

RYSUNEK 1. Liczba serii opcji w obrocie na koniec roku

Źródło: Opracowanie własne na podstawie danych z Roczników Giełdowych z lat 2004-2016. 
Rysunki 2, 3 i 4 prezentują miesięczne wahania wolumenu, wartości obrotu, liczby otwartych pozycji i ich wartości, a także średnią liczbę transakcji oraz średnią liczbę kontraktów na transakcję opcjami indeksowymi na GPW w Warszawie. Czarne pionowe linie zaznaczają miesiąc wprowadzenia zmian w standardach. Analiza tych danych nie wskazuje na istnienie wyraźnej zależności pomiędzy

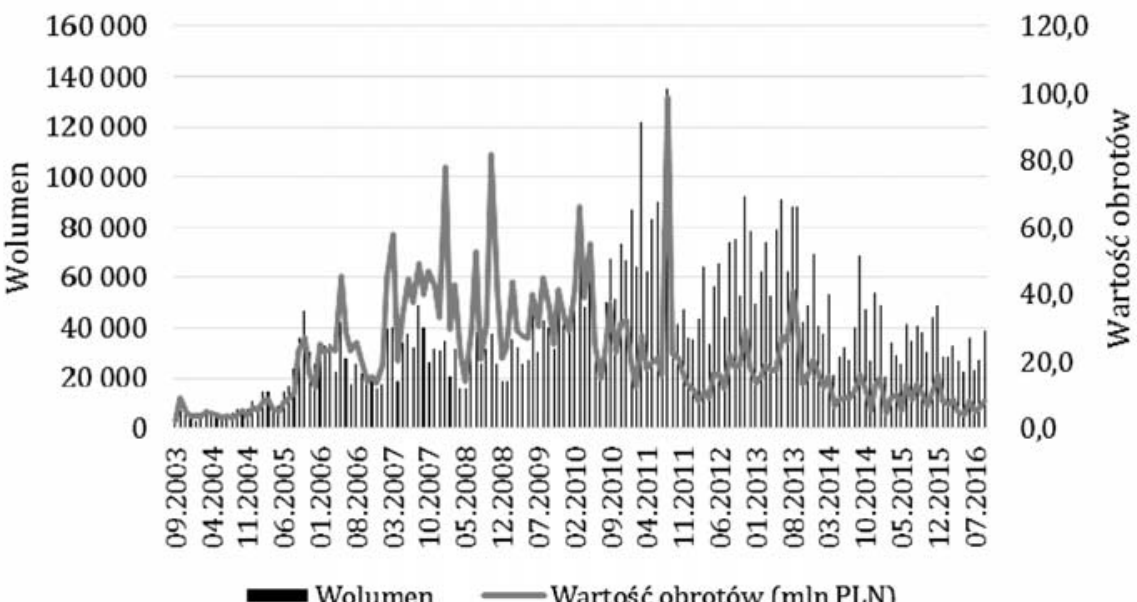

RYSUNEK 2. Miesięczny wolumen i wartość obrotu opcjami indeksowymi na GPW w Warszawie od września 2003 roku do września 2016 roku

Źródło: Opracowanie własne na podstawie danych GPW.

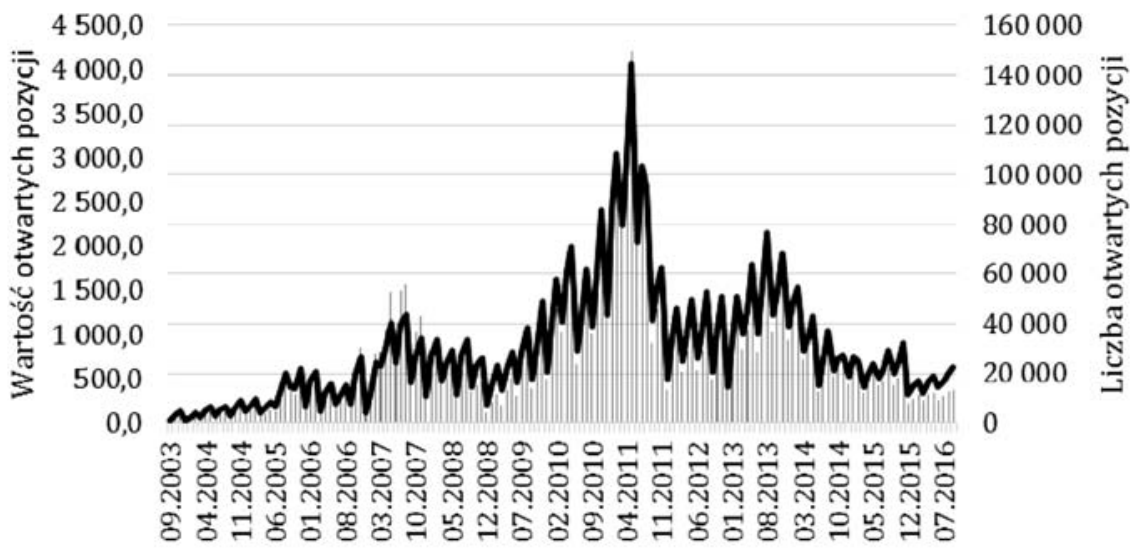

Wartość otwartych pozycji (mln PLN) — Otwarte pozycje (na koniec okresu)

RYSUNEK 3. Liczba otwartych pozycji i ich wartość w ujęciu miesięcznym opcji indeksowych na GPW w Warszawie od września 2003 roku do września 2016 roku Źródło: Opracowanie własne na podstawie danych GPW. 


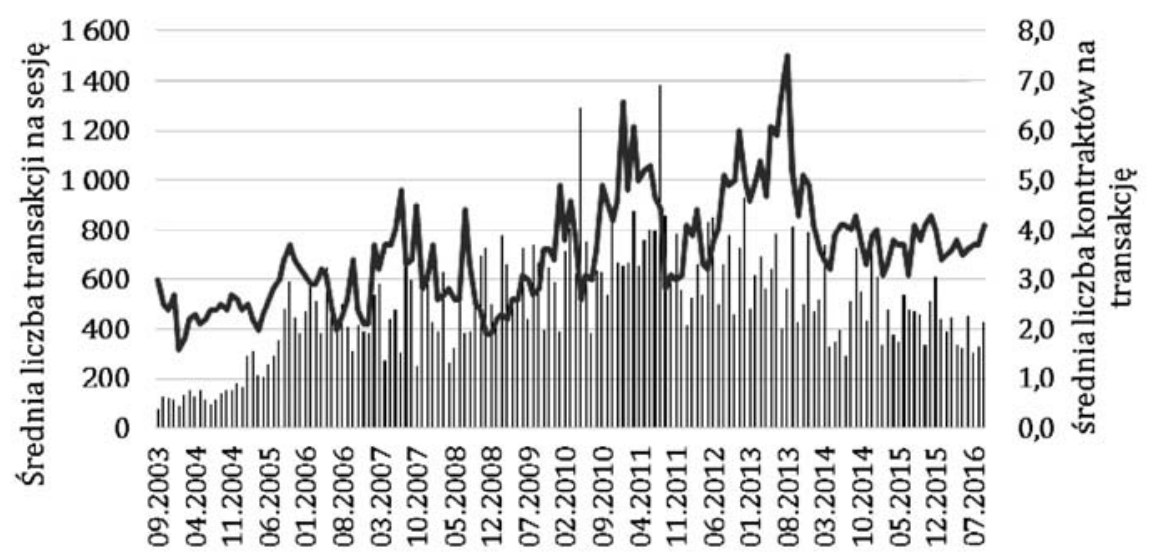

- Średnia liczba transakcji na sesję — Średnia liczba kontraktów na transakcję

RYSUNEK 4. Średnia liczba transakcji na sesję i średnia liczba kontraktów na transakcję w ujęciu miesięcznym opcji indeksowych na GPW w Warszawie od 2003 roku do 2016 roku Źródło: Opracowanie własne na podstawie danych GPW.

momentem wprowadzenia zmian w standardach opcji a znaczącym wzrostem bądź spadkiem badanych wielkości w miesiącu następującym po wprowadzeniu zmian. Największy procentowy, miesięczny wzrost wolumenu obrotu, liczby otwartych pozycji i ich wartości miał miejsce w październiku 2003 roku, czyli tuż po wprowadzeniu tego instrumentu do obrotu. Największą dodatnią (miesięczną, procentową) zmianę wartości obrotów całkowitych i średnich na sesję odnotowano w sierpniu 2011 roku, a największy spadek tych wielkości - w następnym miesiącu - we wrześniu 2011 roku, nie było to jednak związane ze zmianami standardów. Na przestrzeni 13 lat, analizowane wielkości rosły (czasem o ponad 100\% z miesiąca na miesiąc) i spadały (nieraz nawet o 80\%). Zmiany te jednak były spowodowane innymi czynnikami niż modyfikacje standardów.

Wyniki badań porównujących 24-miesięczne średnie wielkości badanych parametrów przed i po wprowadzeniu zmian w standardach w latach 2007-2012 są niejednoznaczne. W niektórych przypadkach badane wielkości rosły, w innych spadały, czasami średnie przed i po zmianach różniły się istotnie statystycznie ${ }^{11}$, czasem nie (tabela 2). Badania dotyczące wspomnianych lat obejmowały okres kryzysu finansowego, dlatego należy interpretować je z dużą ostrożnością.

Szczególną uwagę warto zwrócić na dwie ostatnie zmiany standardów, które miały miejsce w 2014 roku. Spośród wszystkich zmian były one najbardziej znaczące, wprowadzały tzw. opcje miesięczne. Jednocześnie w ich przypadku

${ }^{11}$ Przy poziomie istotności 0,05. 
TABELA 2. Dwudziestoczteromiesięczne średnie wielkości badanych parametrów przed wprowadzeniem i po wprowadzeniu zmian w standardach oraz istotność różnic tych średnich

\begin{tabular}{|c|c|c|c|c|c|c|c|}
\hline \multicolumn{2}{|c|}{$\begin{array}{c}\text { Wielkość } \\
\text { charakteryzująca } \\
\text { rynek opcji }\end{array}$} & \multirow{2}{*}{$\begin{array}{c}\text { Wolumen } \\
25070\end{array}$} & \multirow{2}{*}{$\begin{array}{c}\begin{array}{c}\text { Wartość } \\
\text { obrotów } \\
\text { (mln PLN) }\end{array} \\
19,68\end{array}$} & \multirow{2}{*}{$\begin{array}{c}\begin{array}{c}\text { Średnia } \\
\text { liczba } \\
\text { transakcji } \\
\text { na sesję }\end{array} \\
419,13\end{array}$} & \multirow{2}{*}{\begin{tabular}{|c|}
$\begin{array}{c}\text { Średnia } \\
\text { liczba } \\
\text { kontraktów } \\
\text { na transakcję }\end{array}$ \\
2,78 \\
\end{tabular}} & \multirow{2}{*}{$\begin{array}{c}\begin{array}{c}\text { Otwarte } \\
\text { pozycje } \\
\text { (na koniec } \\
\text { okresu) }\end{array} \\
12978\end{array}$} & \multirow{2}{*}{$\begin{array}{c}\begin{array}{c}\text { Wartość } \\
\text { otwartych } \\
\text { pozycji } \\
\text { (mln PLN) }\end{array} \\
361,88\end{array}$} \\
\hline \multirow{4}{*}{$\begin{array}{l}\hat{\delta} \\
\stackrel{0}{N} \\
\text { ñ }\end{array}$} & przed & & & & & & \\
\hline & po & 29786 & 37,86 & 495,00 & 3,05 & 24710 & 735,38 \\
\hline & $\begin{array}{l}\text { różnica jest } \\
\text { istotna* }\end{array}$ & nie & tak & nie & nie & tak & tak \\
\hline & p-value & 0,099113 & 0,000198 & 0,076459 & 0,201215 & 0,000102 & 0,001017 \\
\hline \multirow{4}{*}{$\begin{array}{l}1 \\
\text { Oे } \\
\text { స̦ } \\
\text { ○े }\end{array}$} & przed & 30416 & 28,52 & 470,71 & 3,11 & 19084 & 627,28 \\
\hline & po & 30129 & 36,20 & 535,29 & 2,76 & 23022 & 550,83 \\
\hline & $\begin{array}{c}\text { różnica jest } \\
\text { istotna* }\end{array}$ & nie & nie & nie & nie & nie & nie \\
\hline & p-value & 0,914069 & 0,088773 & 0,102966 & 0,074279 & 0,189828 & 0,477816 \\
\hline \multirow{4}{*}{$\begin{array}{l}\text { शे } \\
\text { ¿ } \\
\text { î } \\
0\end{array}$} & przed & 30284 & 39,13 & 481,92 & 3,15 & 25156 & 780,39 \\
\hline & po & 49704 & 32,70 & 646,79 & 3,70 & 45462 & 1111,88 \\
\hline & $\begin{array}{l}\text { różnica jest } \\
\text { istotna* }\end{array}$ & tak & nie & tak & nie & tak & nie \\
\hline & $\mathrm{p}$-value & 0,000103 & 0,152324 & 0,002822 & 0,057087 & 0,001157 & 0,058977 \\
\hline \multirow{4}{*}{ 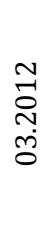 } & przed & 64985 & 28,06 & 731,83 & 4,22 & 66180 & 1727,85 \\
\hline & po & 63039 & 19,13 & 637,25 & 4,87 & 44218 & 1053,36 \\
\hline & $\begin{array}{l}\text { różnica jest } \\
\text { istotna* }\end{array}$ & nie & nie & nie & tak & tak & tak \\
\hline & p-value & 0,772790 & 0,057263 & 0,113763 & 0,049594 & 0,004792 & 0,003187 \\
\hline \multirow{4}{*}{$\begin{array}{l}\dot{+} \\
\stackrel{D}{0} \\
\dot{0}\end{array}$} & przed & 63495 & 18,93 & 633,79 & 4,91 & 44051 & 1047,38 \\
\hline & po & 36488 & 9,89 & 465,17 & 3,75 & 23510 & 535,56 \\
\hline & $\begin{array}{c}\text { różnica jest } \\
\text { istotna* }\end{array}$ & tak & tak & tak & tak & tak & tak \\
\hline & p-value & 0,000003 & 0,000014 & 0,000355 & 0,000040 & 0,000006 & 0,000007 \\
\hline \multirow{4}{*}{ 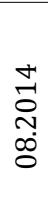 } & przed & 59303 & 18,31 & 580,25 & 4,91 & 42886 & 1035,13 \\
\hline & po & 35913 & 9,23 & 459,78 & 3,71 & 20664 & 445,03 \\
\hline & $\begin{array}{l}\text { różnica jest } \\
\text { istotna* }\end{array}$ & tak & tak & tak & tak & tak & tak \\
\hline & $p$-value & 0,000151 & 0,000044 & 0,012482 & 0,000021 & 0,000002 & 0,000001 \\
\hline
\end{tabular}

* przy poziomie istotności 0,05.

Źródło: Opracowanie własne na podstawie danych GPW. 
porównanie średnich wolumenów czy liczby otwartych pozycji, a także innych badanych parametrów przed i po zmianach standardów wskazuje na statystyczną istotność wszystkich różnic pomiędzy średnimi. Niestety wszystkie wielkości po wprowadzeniu standardów spadły, co wskazuje na wycofanie się inwestorów z rynku opcji indeksowych.

\section{WNIOSKI}

Płynność obrotu jest jednym z głównych czynników decydujących o możliwości zbudowania strategii opcyjnych. Władze Giełdy Papierów Wartościowych w Warszawie podejmują działania mające na celu zwiększenie płynności obrotu opcjami indeksowymi, np. modyfikując standardy opcji, dopasowując je do potrzeb inwestorów i wychodząc naprzeciw ich oczekiwaniom. Celem niniejszej pracy było określenie, czy działania władz giełdy przełożyły się na zwiększone zainteresowanie inwestorów tym instrumentem.

Analiza podstawowych wielkości giełdowego rynku opcji pokazała, że w miesiącu następującym bezpośrednio po wprowadzaniu modyfikacji w standardach nie można zauważyć znaczących zmian wolumenu obrotu czy liczby otwartych pozycji w porównaniu z okresami, gdy standardy nie były zmieniane. Wyraźne i istotnie statycznie zmiany 24-miesięcznych średnich analizowanych parametrów można zaobserwować $\mathrm{w}$ przypadku wprowadzania ostatnich zmian $\mathrm{w}$ standardach w 2014 roku. Wprowadzane wtedy zmiany wydają się najbardziej znaczące w porównaniu z wcześniejszymi (np. wprowadzenie tzw. opcji miesięcznych). Niestety wszystkie analizowane wielkości (m.in. wolumen czy liczba otwartych pozycji) odnotowały spadek po zmianach w 2014 roku, co wskazuje na wycofanie się inwestorów z rynku opcji indeksowych.

Widoczną zmianą, którą należy wiązać ze zmianami standardów jest wyraźny wzrost liczby serii pozostających $\mathrm{w}$ obrocie. Niestety nie przekłada się to na wzrost obrotów, gdyż inwestorzy skupiają się na opcjach o najbliższych terminach wygaśnięcia, prawie nie handlując (lub w niewielkim zakresie) opcjami $\mathrm{z}$ dłuższymi terminami wygaśnięcia lub opcjami będącymi głęboko in-the-money lub głęboko out-of-the-money. Nasz rynek nie jest jednak odosobniony w tym problemie, dotyka on również inne giełdy np. paryską i opcje na indeks CAC40 [François-Heude i Yousfi 2014].

\section{Spis literatury}

ACKERT L.F., TIAN Y.S. 2000: Evidence on the Efficiency of Index Options Markets, Economic Review 85, 1, s. 40-52.

CHOU R.K., CHUNG S., HSIAO Y., WANG Y. 2011: The impact of liquidity on option prices, Journal of Futures Markets 31, 12, s. 1116-1141. 
FRANCIS J.C. 2000: Inwestycje. Analiza i zarzadzanie, WIG-Press, Warszawa.

FRANÇOIS-HEUDE A., YOUSFI O. 2014: On the liquidity of CAC 40 index options market. Journal of Derivatives \& Hedge Funds 20, 3, s. 177-198.

HASBROUCK J., SCHWARTZ R.A. 1988, Liquidity and execution costs in equity markets, Journal of Portfolio Management 14, 3, s. 10-16.

KRÓLIK-KOŁTUNIK K. 2010a: Wycena opcji na WIG20 notowanych na Giełdzie Papierów Wartościowych w Warszawie w oparciu o parytet kupna-sprzedaży [w:] P. Karpuś, J. Węcławski (red.), Rynek finansowy - nowe perspektywy Annales Universitatis Mariae Curie-Skłodowska, Sectio H: Oeconomia, Lublin-Polonia, tom XLIV, Lublin, 2, s. $675-688$.

KRÓLIK-KOŁTUNIK K. 2010b: Zastosowanie strategii arbitrażowej box na przykładzie opcji indeksowych notowanych na Giełdzie Papierów Wartościowych w Warszawie [w:] M. Kalinowski, M. Pronobis (red.), Innowacje na rynkach finansowych, CeDeWu, Warszawa, s. 167-180.

KRÓLIK-KOŁTUNIK K. 2012: Efektywność strategii inwestycyjnych na rynku opcji indeksowych na Giełdzie Papierów Wartościowych w Warszawie, rozprawa doktorska, nieopublikowana.

MO C. 2015: Option Bid-Ask Spread and Liquidity, Journal of Trading, 10, 3, s. 44-56.

OSTROWSKA E. 2011: Portfel inwestycyjny klasyczny i alternatywny, Wydawnictwo C.H. Beck, Warszawa.

Roczniki Giełdowe z lat 2004-2016, www.gpw.pl/biblioteka-gpw-lista?gpwlc_id=10

\title{
THE INFLUECNE OF OPTIONS STANDARDS CHANGES ON THE INDEX OPTIONS MARKET ON WARSAW STOCK EXCHANGE
}

\begin{abstract}
Options are derivative financial instruments that allows the construction of a number of investment strategies. The condition of the building is adequate variety of instruments and liquidity. The authorities of the Warsaw Stock Exchange modify the standard options responding to the needs of investors. The aim of this study is to verify if the actions in this area resulted in increased interest in index options on the Warsaw Stock Exchange. The studies analyzed the various parameters of options market include the number of series, the volume and value of trading and the number of open positions.
\end{abstract}

Key words: index options, derivatives, stock exchange, capital market 